\title{
INTENSIFICATION OF THE LEGISLATIVE PROCESS: THE EXPERIENCE OF SERBIA
}

Konstantin A. Polovchenko ${ }^{1}$

\begin{abstract}
The article presents an analysis of the legislative process in the Republic of Serbia. The leading method in this study is a systematic approach that allowed analyzing the specifics of the stages of the legislative process in terms of ensuring its effectiveness and efficiency. Studying the peculiarities of the lawmaking of the National Assembly of the Republic of Serbia, the author concluded that the modern constitutional legislation of Serbia provided for the intensification of the legislative process, which, in turn, made it possible to update, develop and increase the current legislative array of the Republic of Serbia within a fairly short period.
\end{abstract}

Keywords: legislative power, legislative initiative, separation of powers, functions of parliament, the promulgation of the law, amending the constitution.

\section{Introduction}

According to Article 1 of the 2006 Constitution, the Republic of Serbia is a state based on the rule of law and the principles of civil democracy. The governmental structure of the Republic is based on the separation of powers into legislative, executive and judicial. The relations of the three branches of government are based on balance and mutual control. The National Assembly is the unicameral highest representative body in the Republic of Serbia; it consists of two hundred and fifty people's deputies elected by direct election by secret ballot. Also, under the 2006 Constitution of the Republic of Serbia, the National Assembly carries out a wide range of functions: budgetary, control, electoral, quasi-judicial, and, of course, the lawmaking function.

The Republic of Serbia pose no exception to the rule that when examining the role of parliament in the socio-political process of any state, the

\footnotetext{
${ }^{1}$ MGIMO University, Moscow. Email: kpolovchenko@gmail.com.
} 
attention should certainly be paid not only to the breadth of functions of the representative body but also to the features of parliamentary procedures, which often have a decisive influence on the content of decisions made by the representative body. Thus, Henry Martyn Robert attached much more importance to parliamentary procedures than even to the substance of the addressed issues. He noted, in particular: 'The presence of a procedural rule is much more important than its content because its existence provides a uniform discussion of the case, which does not depend upon the caprice of the chairman, the session or mood of its participants'. That is why the most important procedural rules are most commonly enshrined directly in constitutions or special laws on parliament, and described in detail in parliamentary regulations. This primarily concerns lawmaking procedures, since the adoption of laws and other normative acts continues to be the main focus of the parliaments of modern states. The Parliament of the Republic of Serbia also known as the National Assembly poses no exception as well.

Thus, according to Article 98 of the Constitution of the Republic of Serbia, the National Assembly is the bearer of the constituent and legislative power in the Republic of Serbia. The Assembly has the right to adopt a law on any matter within the competence of the Republic of Serbia. Moreover, the 2006 Constitution provided for three exceptions to this rule: territorial changes of the Republic of Serbia, regulating the substantial autonomy of the province of Kosovo and Metohija, as well as creating new autonomous territories and, respectively, abolishing and merging the existing ones. The above issues may be regulated solely as part of the procedure for amending the Constitution. In this case, along with the National Assembly, the constituent power is also exercised by citizens within the framework of the referendum institute.

When it comes to immediate parliamentary procedures in the National Assembly, Article 53 of the Law on the National Assembly lists all of the types

\footnotetext{
${ }^{2}$ Robert, H. Robert's Rules of Order // Washington, 1992. P. 24
} 
by which the Serbian Parliament renders decisions (for example, the ratification of international treaties, the adoption of the budget, the procedure for prior approval for the charter of the autonomous region, the procedure for adopting an urban development and/or spatial plan, legislative and constituent procedures, etc.).

Detailed regulation of the procedure for adoption of laws is presented in the Rules of Procedure of the National Assembly, which regulates, in particular, the procedure administrating the legislative process, the rights and obligations of deputies and deputy groups in the implementation of legislative activities, the requirements for legislative bills and amendments, and other issues related to the process of adoption of laws. Moreover, as observed by professor Stojanović, to prevent parliamentary obstruction, the Assembly repeatedly resorted to amending and supplementing its Rules of Procedure. ${ }^{3}$ As a matter of fact, it is the normative regulation of law-making procedures that is the subject of the presented article.

\section{Methods}

The object of this study is a complex of constitutional-legal relations arising from the passage of legislative and constituent processes in the Republic of Serbia. The research undertaken in the article was conducted using several general scientific and special methods of cognition and research. Like other postsocialist states of Europe, with the transition to a new socio-political and economic system, Serbia faced the problem of adopting a huge array of new legislation that would ensure the formation of liberal democratic foundations of the state structure of the Republic. Therefore, a pressing need arose to ensure an adequate regulatory framework for the legislative activity of the National Assembly of the Republic of Serbia. As a result, the legislative process in Serbia has been significantly intensified through the introduction of several special institutions. The leading method in this study is the system analysis, which allowed analyzing the specifics of the stages of the law-making process in terms of ensuring its effectiveness and efficiency. Also, the

\footnotetext{
${ }^{3}$ Stojanović, D. Constitutional law (In Serb.) / Niš, 2009: 250
} 
special legal method peculiar to this study was actively used in analyzing particular constitutional and legal establishments such as institutes of legislative initiative and promulgation.

\section{Results and discussion}

\subsection{The legislative process}

Professor Pajvančić described the legislative process as one of the most important and most frequently used decision-making procedures in the practice of the National Assembly. Accordingly, this process is regulated in detail by the Rules of Procedure of the National Assembly. ${ }^{4}$ The Serbian doctrine distinguishes four main stages of the legislative process: 1) legislative initiative; 2) discussion of the draft bill in the committees of the National Assembly; 3) discussion at the plenary meeting of the National Assembly and adoption of the law; 4) approval and promulgation of the law. ${ }^{5}$ In addition to the general rules of the legislative process, the Rules also provide for the practice of expedited adoption of laws.

\footnotetext{
${ }^{4}$ Pajvančić, M. Constitutional law (In Serb.) / Novi Sad, 2014: 198.

${ }^{5}$ Stojanović, D. Constitutional law (In Serb.) / Niš, 2009: 251
}

Referring to the first stage of the legislative process (legislative initiative), as per Constitution of Serbia, each deputy, the Government of Serbia, the assembly of the autonomous region, as well as at least 30,000 voters, have the right to introduce legislative proposals, as well as to draft other general acts. Thus, the Serbian Constitution provided for the right of popular legislative initiative. Moreover, the amount of necessary 30,000 voters for submitting the draft to the National Assembly seems somewhat overstated, considering that the population of Serbia has a little more than seven million people. ${ }^{6}$ This is probably why the bills submitted within the framework of the institute of the popular initiative are almost imperceptible in the total volume of bills submitted to the National Assembly annually by the subjects of the law of legislative initiative. Besides, such institutes as the Protector of Citizens and the National Bank of Serbia also have this right of legislative initiative in matters within their competence (Article 107). The subject of the right of the

\footnotetext{
${ }^{6}$ According to the Republican Statistical Institute of the Republic of Serbia, as per 01/01/2017, the Serbian population accounted for 7,040,272 people (excluding the data for the Autonomous Province of Kosovo and Metohija).
} 
legislative initiative has to present a bill with the proper substantiation. According to Part 2 of Article 151 of the Rules of Procedure the National Assembly, such substantiation must contain the constitutional and legal basis for the adoption of the law; the grounds for the adoption, which should include: an analysis of the current situation, the problems that the bill is aimed at solving, the tasks that the bill is pursuing, the possibilities for solving the problem without adopting the new law, and also rational explanation of why the adoption of the law is the best way to solve the corresponding issues; the substantiation should also list the justification of the main legal institutions; assessment of financial resources necessary for the implementation of the law, including sources of support for these funds; and consideration of the provisions of existing laws that are subject to change or amendment (by striking out part of the text that is changing, and the new text is entered in capital letters). If the draft bill contains provisions that have a retroactive effect, then it is necessary to substantiate the common interest of the subject of the legislative initiative that introduced the bill when it provided for
755

the retroactive effect of certain provisions of the draft law. Whether, however, an expedited procedure is proposed for the adoption of the law, the grounds for the adoption of the law as part of the expedited procedure should also be narrowed down.

Furthermore, the substantiation may include an analysis of the consequences of the proposed law, which may include the following explanations: who and how will most likely be influenced by new legislative decisions; what costs the application of the law will entail for citizens and the economy (especially for small and medium-sized businesses); as well as whether the positive consequences of the adoption of the law justify the costs that it requires; whether the creation of new business entities and effect on market competition are covered by existing laws; whether the interested parties had an opportunity to define their position, and what measures during the application of the law have to be taken to achieve the conditioned result of the adoption of this law. As it could be concluded from the foregoing, the Rules of Procedure of the National Assembly thoroughly established the requirements 
associated with the justification of the feasibility, relevance, and content of the bill introduced by the subject of the legislative initiative.

It should be noted that in addition to the draft bill, the subject of the legislative initiative who introduced the draft is required to submit a statement on the compliance with the provisions of the European Union legislation or on absence of the obligations to adjust with or that the bill cannot be harmonized with legal acts of the European Union, as well as a conformity table on the harmonization of the bill with the provisions of EU legislation. The foregoing is undoubtedly of particular importance concerning Serbian endeavor for European-wide integration, declared in the 2006 Constitution.

Also, if the requestor is represented by a group of deputies, then along with the legislative proposal, a document should be submitted establishing the appointment of a representative of the subject submitting the bill. In the absence of such a document, it is considered that the representative of the subject of the legislative initiative is the deputy, whose signature under the bill goes first.
756

According to Article 152 of the Rules, a draft bill submitted to the National Assembly is forwarded (immediately after registration) by the President of the National Assembly to the deputies, the relevant committee, and the Government if the latter is not the subject of the legislative initiative that introduced the draft. The bill is also forwarded to the Protector of Citizens or the National Bank of Serbia if it regulates matters within their competence.

If the draft law has not been prepared following the requirements of the Rules, the President is obliged to suggest the subject of a legislative initiative to bring the draft law in line with the provisions of the Rules with an exact indication of the inconsistencies identified.

The subject of the legislative initiative has the opportunity to alternatively respond to the comments of the President of the Serbian parliament. Thus, the requestor may refuse the bill. Whether the subject of the legislative initiative introducing the bill to the National Assembly considers this unsuitable, then this party is still provided with 15 days to amend the bill, 
eliminating the inconsistencies indicated by the President of the Assembly or disagree with the stated opinion. In this case, the subject has to request the National Assembly to express its position on the issue of compliance of the bill with the requirements of the Rules in writing. Moreover, the Assembly is obliged to state its position on this issue at the first meeting before considering the agenda of the corresponding day without any debate. Before a decision is made by the Assembly, the subject of the legislative initiative introducing the bill has the right to substantiate its position within the term of no more than five minutes. Noteworthy that according to statistics, the above procedure in the National Assembly is a rather rare (even exceptional) phenomenon, most commonly, the requester independently eliminates the shortcomings, satisfying the requirements of the President. As a general rule, a draft bill prepared under the requirements of the law is included in the agenda of the meeting of the National Assembly within 15 days from the day it was submitted.

An important role in determining the future bill is played by the relevant committee of the National Assembly, as well as by the Government of Serbia if the latter is not the very body that introduced the bill. In fact, the consideration of the bill in the relevant committee is the second stage of the legislative process in Serbia. Thus, before being reviewed at a meeting of the National Assembly, the bill is subject to consideration by the relevant committee and the Government. It is the abovementioned bodies that notionally recommend in their report (conclusion) to the National Assembly to accept or reject the bill. At the same time, if the relevant committee and the Government propose to adopt the bill in general, then, in this case, they must indicate whether this recommendation concerns the bill to be adopted as a whole or with the amendments and additions that are proposed in the form of amendments. Thus, according to Part 3 of Article 155 of the Rules of Procedure, pursuant to the general rule, the relevant committee and the Government submit a report (conclusion) to the National Assembly no later than five days before the day of Assembly meeting, which is scheduled to consider the draft law. 
When it comes to the discussion in the relevant committee, first of all, a general discussion of the bill is given at the corresponding meeting, followed by the clause-by-clause detailed review. The latter is held on the amended clauses and articles of the draft; the following officials are entitled to take part in the discussion: members of the committee, subject (or representative) of legislative initiative introducing the draft law, representative of the Government, sponsor of an amendment(s), people's deputies present at a meeting of the relevant committee, as well as other invitees. After the discussion is done, the relevant committee submits a report to the National Assembly which contains the opinions and suggestions of the committee, as well as the special opinion of its members (if any); according to statistics, there could be quite a lot of them. The committee appoints a spokesperson who is entitled to justify the position of the committee at a meeting of the National Assembly.

Special attention should be given to amendments to the bill. Thus, according to Article 161 of the Rules of Procedure of the National Assembly, an amendment is a proposal to amend and supplement the bill. An amendment can be made both by the subjects of the right of legislative initiative (which is provided for by the Constitution) and by the relevant Assembly committee. Amendments are submitted to the President of the National Assembly, in writing or electronically, starting from the day the bill is registered in the Assembly, but no later than three days before the date of the meeting at which consideration of the bill is proposed. The sponsor of an amendment cannot independently, or together with other people's deputies, submit several amendments to the same article of the draft law (Article 161 of the Rules of Procedure of the National Assembly).

As for the requirements imposed by Serbian legislation on the content of amendments to draft bills, they should contain the corresponding article of the Rules as a legal basis for submitting the amendment; article number of the amended bill; full text of the amendment; a justification containing an explanation of the proposed text of the amendment and the purpose pursued by its adoption, as well as, if necessary, an assessment of the impact of the proposed amendment on 
budgetary funds. It should be also noted that the Uniform Methodological Rules for the Drafting of Regulations are applied in amendments composition as well (Part 2 of Art. 162 of the Rules).

The President of the National Assembly directing the well-timed submitted amendments to the subject of the legislative initiative, to the people's deputies, the relevant committee and the Government. Moreover, the committee is endowed with the right to reject meaningless (or even insulting) amendments, notifying the National Assembly in a special report. In case the deadline has not been met, the SecretaryGeneral of the Assembly informs the persons and authorized bodies that the amendments were not submitted on time. As a result, the rejected and untimely submitted amendments cannot be the subject of discussion; also, voting is not held on this count.

Note should be made of that the subject of the legislative initiative that introduced the bill, as well as the relevant committee, are considering amendments to the bill and also submitting proposals to the National Assembly on amending and rejecting the very same amendments. Whether the amendment is consistent with the Constitution and supported by the subject who submitted the bill (as well as by the relevant committee), then, in this case, the amendment becomes an integral part of the bill and the Assembly does not take any special decisions on that matter.

The third stage of the legislative process in Serbia is its discussion at the plenary meeting of the National Assembly. An integral feature of the legislative process in Serbia, or rather a feature of the consideration of the draft bill at the plenary meeting of the Assembly, is that this consideration is 'single-stage" 7 , i.e. the procedure for considering the bill at the plenary meetings of the Assembly is not broken down into readings. The Assembly may decide to hold a general debate on several bills that are on the agenda of the same meeting and are related to each other by the subject or procedure for its decision. As regards the draft bill, the plenary session, first of all, holds a general debate, which results in a vote on the potential adoption of the draft. If

\footnotetext{
${ }^{7}$ Pajvančić, M. Constitutional law (In Serb.) / Novi Sad, 2014: 199
} 
people's deputies agree in principle with the draft bill, then a clause-by-clause discussion of the bill is held. At the same time, clause-by-clause discussion, as a general rule, is held no earlier than 24 hours after the end of the general debate. During the period between the completion of the general debate and the opening of a clause-by-clause discussion of the draft bill, the relevant committee is entitled to amend it. However, concerning certain bills, the Assembly has the right to decide on holding a clause-by-clause discussion immediately after the end of the general debate of the draft bill (Part 7 of Article 157 of the Rules of Procedure of the National Assembly).

A clause-by-clause discussion of the draft bill is carried out in respect of only those articles to which amendments have been proposed, as well as those amendments that require the inclusion of new provisions in the bill, while the total time for clause-by-clause discussion for parliamentary groups equals the time allotted for general debate. Moreover, the allotted time is distributed between deputy groups in proportion to the number of members of the corresponding deputy group (Part 2 of Article 158 of the Rules of Procedure of the National Assembly).

Prior to the relevant Decision of the Constitutional Court, the Rules have limited the participation in the debate on amendments only to the sponsor of an amendment, the subject of the law of the legislative initiative who introduced the bill to the National Assembly, the speaker of the relevant committee, the chairman of the deputy group, and the authorized representative of the Government. According to the Constitutional Court, such provisions of the Rules of Procedure did not comply with the Constitution of Serbia, since they limited the right of the people's deputies to express their opinion on everything that is discussed in the National Assembly. ${ }^{8}$

To optimize the legislative process, the Rules also significantly limited the time for participants to take part in discussions. Thus, each entity proposing an amendment to the bill has the right to submit a corresponding substantiation for such amendment but

\footnotetext{
${ }^{8}$ Constitutional Court Decision IU 61/01/ Official Gazette RS 16/04
} 
only within the two minutes timeframe. Furthermore, the requestor of the bill also has the right to submit an opinion on each amendment for up to two minutes, so that the total length of a clause-byclause discussion on this basis does not last more than three hours. People's deputies, who are not members of deputy groups, being determined by agreement of no more than three participants to the discussion, are entitled to speak out on their position for up to five minutes. Whether the mutual agreement is still not reached, then three people's deputies, who were the first to sign up for the speech, have the right to deliver another speech for up to five minutes.

During the clause-by-clause discussion of the draft bill, amendments in a written form are entitled to be submitted only by the subject of the legislative initiative introducing the draft, the relevant committee, as well as the Government, and only if the need for the adoption of the amendment arose because of the previous adoption of the other amendment. Besides, whether due to the adoption of one or more amendments it becomes necessary to conduct a technicality revision of the text of the draft bill, or if it becomes necessary to harmonize the amendments with each other and with the statutory wording, the National Assembly has the right to postpone the decision and request the Committee on Constitutional and Legislative Issues to conduct a corresponding technicality revision of the text of the law; the relevant committee is obliged to harmonize the adopted amendments with each other and with the statutory wording at a specially allotted time. The National Assembly makes a special decision on each amendment; the vote on amendments follows the order of articles of the bill. If several amendments have been submitted to one article, a vote shall first be taken to exclude certain provisions of the relevant article, then by an amendment that provides for a change to the entire article. Voting is not held on amendments that were supported by the subject that introduced the bill, the relevant committee, and the Government, as they become an integral part of the bill. After the President of the Assembly determines that there is no one more willing to present their position, and also after the time set for a clauseby-clause discussion exhausted, the 
President closes the debate and announces the vote on the bill as a whole.

Thus, after deciding on the amendments, the National Assembly votes on the bill as a whole. If amendments to the bill have not been submitted, then after the adoption the Assembly decides on principle agreement with such a bill.

As can be seen from the above, the National Assembly renders three main types of decisions related to the adoption of laws: the decision on principle agreement with the bill, the decision to amend the bill, and on the bill as a whole. ${ }^{9}$ Certainly, the Assembly renders a decision to amend only if the bill is principally agreed with. The quorum for decision-making is the absolute majority of deputies, that is, the presence of at least 126 deputies. Therefore, to adopt the law, more than half of the quorum necessary for decision-making, thus, at least 64 people's deputies have to vote for its adoption. ${ }^{10}$
Moreover, according to Part 3 of Article 105 of the Constitution of Serbia, 'By means of majority vote of all deputies, the National Assembly shall decide on laws which regulate: 1) referendum and national initiative; 2) enjoying of individual and collective rights of members of national minorities; 3) development plan and spatial plan; 4) public debt; 5) territories of autonomous provinces and local self-government units; 6) conclusion and ratification of international contracts; 7) other issues stipulated by the Constitution'. "The original text of the adopted law is stamped by the National Assembly; it remains deposited in the National Assembly as well.

Particular attention should be paid to the adoption of the law as part of an accelerated legislative procedure. Thus, according to Article 167 of the Rules of Procedure of the National Assembly, the law can be adopted in the order of an expedited procedure. This is the procedure to adopt the law regulating issues and relations arising as a result of

\footnotetext{
${ }^{10}$ According to Article 100 of the Constitution of the Republic of Serbia, the composition of the National Assembly includes 250 people's deputies.
}

\footnotetext{
${ }^{9}$ Also, according to Article 160 of the National Assembly Rules of Procedure, 'Where a bill contains provisions which envisage retroactive effect, the National Assembly shall vote separately on whether such an effect is in the general interest'.
} 
circumstances that could not be foreseen, and failure to enact laws acceleratedly can have harmful consequences for the human life and health, the security of the country and the activities of bodies and organizations, as well as for fulfillment of international obligations and harmonization of legal acts with the European Union legislation. In this case, the subject of law of the legislative initiative that introduced the bill is obliged to state the reasons for the adoption of the law in the order of expedited procedure.

A bill that is proposed for the expedited procedure may be included in the agenda of the National Assembly meeting if submitted no later than 24 hours before the relevant meeting. At the same time, even shorter terms for inclusion on the agenda of the meeting of the Serbian Parliament are envisaged regarding issues related to the protection of the state and society from external and internal threats. Thus, according to Part 2 of Article 168 of the Rules of Procedure of the National Assembly, the bill regulating defense and security issues, the adoption of which is proposed for expedited proceedings, can be included in the agenda of the Assembly meeting even if it is presented on the day of the meeting two hours prior to opening session; also, if the bill is introduced by the Government of Serbia, it can be included on the agenda even if it is presented during the meeting of the National Assembly, provided that the meeting will be attended by the majority of the total number of deputies. On any proposal to include bills following expedited procedures to the agenda, the National Assembly renders a decision without a debate. Moreover, the Speaker of the Serbian Parliament is obliged to submit a bill, for consideration of which an expedited procedure is proposed, to deputies and the Government immediately after its receipt. However, discussions on the 'expedited' bill can begin immediately, without additional provision of information and reports of the relevant committee and the Government; amendments to such a bill can be submitted no later than the start of the debate.

When it comes to the last stage of the legislative process (promulgation of the law), the President of Serbia has this right as head of state. Thus, according to Article 113 of the Constitution, the President of the 
Republic is obliged, no later than 15 days after the adoption of the law (or no later than 7 days, if the law was adopted by expedited procedure) to issue a decree promulgating the law, or return the law to the National Assembly with the written justification for reconsideration. Whether, with regard to the above mentioned, the National Assembly takes the decision to hold a second vote on the law, which the President of the Republic imposed a veto over and returned for reconsideration; in this case, the law is to be adopted by a majority of the total number of people's deputies. The President of the Republic is obliged to promulgate the repassed law. If the President of the Republic does not enact an ordinance on promulgation of the law within the period provided for by the Constitution, then such a decree shall be issued by the President of the National Assembly.

According to Article 196 of the Constitution of Serbia, laws are officially published before they enter into force. The official republican press agency in which laws are officially published

\footnotetext{
${ }^{11}$ Official Gazette of the Republic of Serbia

12 Stojanović, D. Constitutional law (In Serb.) / Niš, 2009:254

${ }^{13}$ According to Part 5 of Article 160 of the Rules of the National Assembly of the Republic of
}

before entering into force is the Official Gazette of the Republic of Serbia. ${ }^{11}$ Laws shall enter into force no earlier than the eighth day from the date of official publication. Consequently, as noted by professor Stojanović, the time that must pass from the moment of official publication to the entry into force of the law, vacatio legis or 'idling for the law' is most commonly consist of seven days. $^{12}$ At the same time, the Constitution of Serbia allows for the law to enter into force earlier than the specified period only by virtue of particularly justified reasons established in the process of its adoption. ${ }^{13}$ The Constitutional Court of Serbia in its Decision IU 72/02 indicated that the provisions of the general act providing that this general act enters into force on the day of adoption do not comply with the provisions of the Constitution, which stipulates that the law, another normative act or general act enters into force not earlier than on the eighth day from the day of official publication, unless it is stipulated that due to the presence of certain justified reasons it may enter into

Serbia, 'If the Bill stipulates that the law comes into effect less than eight days after its publication, the National Assembly shall vote separately on whether there are particularly justified reasons for that'. 
force earlier, but not earlier than the day of its official publication. ${ }^{14}$

The Constitution of Serbia also imposed a ban on the retroactive effect of the law. However, Part 2 of Article 197 of the Constitution of Serbia stipulates that only certain provisions of the law can be retroactive and only as an exception when this is required by the 'general interest' established upon adoption of the law. Thus, Part 4 of Article 160 of the Rules of Procedure of the National Assembly specifically stipulates that if the draft bill contains retroactive provisions, the National Assembly takes a separate decision, establishing whether there is a 'general interest' as the basis for providing the relevant provisions with retroactivity. Besides, the provision of the criminal law can be retroactive only if it mitigates the responsibility of the person who committed the crime (Part 3 of Article 197 of the RS Constitution).

It should be noted that the National Assembly has not only the right to adopt laws but also the right to give their authentic interpretation. An authentic interpretation of the rule of law is a kind of official interpretation given by the issuing authority. Thus, the authentic interpretation of the norms of the law carried out by the National Assembly is a direct explanation of their meaning; it is generally binding on all law enforcers. The Rules of Procedure of the National Assembly regulate the adoption of an authentic interpretation of laws. Thus, according to Article 194 of the Rules, the proposal to adopt an authentic interpretation of the law can be introduced by the subject of the legislative initiative. As mentioned above, under the 2006 Constitution such subjects may include people's deputies, the Government, the Assembly of the autonomous region, and at least 30,000 voters, as well as (within their competence) the Protector of Citizens and the National Bank of Serbia (Article 107 of the RS Constitution). If the relevant committee concluded that such a proposal is justified, then it prepares a draft of an authentic interpretation, which is to be directed to the requester of a proposal and to the National Assembly to render a corresponding decision. Whether the committee concluded that

\footnotetext{
${ }^{14}$ Constitutional Court Decision IU 72/02 / Official Gazette RS 8/04
} 
such a proposal is unjustified, then it notifies the subject of the right of the legislative initiative that has proposed the adoption of an authentic interpretation, and the National Assembly, which makes the final decision on an authentic interpretation proposal. However, if the National Assembly takes a positive decision on the need for such an interpretation, then it obliges the relevant committee to develop a draft of the latter. In the course of its consideration and adoption, the National Assembly, following Article 195 of the Rules, applies the provisions of the Rules governing the adoption of the law as part of the adoption of an authentic interpretation, unless otherwise provided by the Rules.

\subsection{Constituent process}

The constituent process in the Republic of Serbia deserves special attention. It should be noted that the current Constitution of Serbia of 2006 made significantly simplifying adjustments to the procedure for amending the Constitution compared to the previous Constitution of 1990. Under the 2006 Constitution, the National Assembly has the authority to adopt and amend the Constitution.

Thus, following current Basic Law, the procedures for reviewing and amending the Constitution are coinciding.

A proposal to amend the Constitution may be submitted by at least one-third of the total number of people's deputies, the President of the Republic, the Government, or by at least 150,000 voters; such a proposal is to be submitted in writing and with proper substantiation. The select committee ensures that the proposal is submitted by a person authorized by the Constitution and in the prescribed manner. The National Assembly considers the proposal at the next meeting not earlier than thirty days from the date of submission. According to Part 2 of Article 143 of the Rules of Procedure of the National Assembly, the sponsor of an amendment to the Constitution should be present at the meeting, at which the proposal is discussed; however, the proposal cannot be amended during the discussion. At the end of the discussion, the National Assembly has to render a decision on the amendment of the Constitution. The proposal is accepted by the Assembly by a two-thirds majority of the total number of deputies. Whether the aforementioned 
majority is not achieved, then the corresponding proposal to amend the Constitution cannot be reconsidered during the next year (Part 4 of Article 203 of the RS Constitution).

If the National Assembly accepts the proposal to amend the Constitution, then it proceeds to develop, respectively, the consideration of an act amending the Constitution. According to Article 149 of the Rules of Procedure of the National Assembly, the provisions of the Rules governing the procedure for adoption of the law apply with due regard to the procedure for amending the Constitution, unless the Rules themselves provide otherwise.

The select committee of the National Assembly plays a significant role in the adoption of the amendment to the Constitution. Thus, according to Article 144 of the Rules, the committee approves the draft act on amending the Constitution (with corresponding justification), and also the draft constitutional law on amending the Constitution, by a majority of the total number of committee members. Having proposed to amend the Constitution, the subject of the legislative initiative is invited to a meeting of the select
767

committee. If the requester appears to be a group of people's deputies or voters, their representative is invited to a meeting of the select committee. Whether such representative remains undefined, then the very first deputy, who signed the draft and, respectively, the voter, are invited to the meeting of the committee. The select committee submits a draft act on amending the Constitution and a draft constitutional law on amending the Constitution to the President of the National Assembly; the latter immediately passes the draft to people's deputies.

Noteworthy that before the adoption of the relevant Decision by the Constitutional Court of Serbia, the Rules of Procedure of the National Assembly limited the pool of participants of the debate on the amendment to the Constitution at the meeting of the National Assembly only to the person who submitted the draft, the representative of the select committee, the chairman of the deputy group, and the authorized representative of the Government. However, the Constitutional Court established by one of its decisions that the above provision of the Rules does not comply with the 
Constitution since it limits the right of the people's deputy to express an opinion on everything that is discussed in the National Assembly. ${ }^{15}$

The Act on the amendment of the Constitution is adopted by a qualified two-thirds majority of the deputies. At the same time, the National Assembly can decide on the need to approve such an act in a republican referendum. This ipso facto refers to a non-binding constitutional referendum. As a result, if the National Assembly decided not to pass an act amending the Constitution to a referendum, then the amendment to the Constitution is adopted by voting in the National Assembly, and the act on amending the Constitution comes into force after being proclaimed by the very same Assembly. However, in accordance with paragraph 7 of Article 203 of the Constitution, the National Assembly is obliged to submit an act amending the Constitution for approval by a republican referendum, if such amendments concern the preamble of the Constitution, the principles of the Constitution, fundamental rights and freedoms and minority rights, the

\footnotetext{
${ }^{15}$ See: Constitutional Court Decision IU 61/01

${ }^{16}$ Stojanović, D. Constitutional law (In Serb.) / Niš, 2014: 167
}

establishment of public authority, the declaration of martial law and a state of emergency, and restriction of human and minority rights in a state of emergency and martial law or constitutional amendment procedures. From the foregoing, professor Stojanović draws the fair conclusion that a referendum appears non-binding only if amendments to the Constitution affect the economic structure and public finances, the competence of the Republic of Serbia, the Constitutional Court, the territorial division, as well as the constitutional and legal provisions of the Constitution. ${ }^{16}$

In the case of an act on amending the Constitution is submitted to a referendum for its approval, citizens have to express their will no later than 60 days after the adoption of the act on amending the Constitution. Moreover, a change in the Constitution is adopted by a simple majority of citizens voted for it in a referendum (Part 9 of Article 203 of the RS Constitution). It should be noted that, unlike some particular European states, ${ }^{17}$ the Constitution of Serbia does not require that the number of people

\footnotetext{
${ }^{17}$ Such as France, Hungary, and Macedonia
} 
participating in a referendum exceeds half of the total number of voters.

\section{Conclusions}

Thus, taking into account the experience of past years and trying to prevent the 'cumbersomeness' of the legislative process, the current legislation of Serbia provided for a simple legislative process (it has four stages and it is not split into readings in the National Assembly), which, allowed updating and developing the modern legislative array of the Republic of Serbia, This tremendous success in legislative process was achieved in a mere ten-year period and generally meets highest European standards. There is a good reason that all stages of the legislative process are accompanied by requirements related to the harmonization of the bill and amendments with the current legal framework of the European Union, which reflects the Serbian endeavor for European-wide integration. Currently, the regulation of the legislative process in Serbia is distinguished by a clear time frame for all stages and procedures, which again helps to optimize the legislative process. Of particular interest among the new laws of the Serbian legislative process is the procedure of adopting the law in expedited proceedings aimed to prevent harm to the life and public health, as well as to ensure the immediate defense and state security. Also, both the people's institute of the legislative initiative stipulated by the 2006 Constitution, as well as the retroactive effect of certain provisions of the law to ensure the 'general interest' (which is given special recognition in the Serbian legislative process) merit serious attention.

When it comes to the constituent process in the Republic of Serbia, the current Constitution of Serbia of 2006 modified the procedure for changing the Constitution compared to the previous Constitution of 1990, greatly simplifying and substantively supplementing it. As a result, the constituent function is currently being carried out by the National Assembly along with citizens of the Republic of Serbia, who, as part of a non-binding or mandatory republican referendum, take part in the procedures for amending the Constitution. Until now, the updated constituent procedure has never been used, and the constitutional updates were 
performed through the adoption of interpretative decisions by the Constitutional Court of Serbia.

\section{References}

The 2006 Constitution of the Republic of Serbia / 'Službeni glasnik' Official Gazette of the Republic of Serbia 98/06.

The Law on National Assembly / Official Gazette RS 9/10.

Rules of Procedure of the National Assembly of the Republic of Serbia / Official Gazette RS 52/10, 13/11, 20/12.

Law on Referendum and People's Initiative / Official Gazette RS 48/94, $11 / 98$.

Constitutional Court Decision IU 61/01 / Official Gazette RS 16/04.

Constitutional Court Decision IU 72/02 /

Official Gazette RS 8/04.

Constitutional Court Decision I U61/01/

Official Gazette RS.
Jovičić, M. Big constitutional systemselements for a comparative constitutional law / Belgrade, 1984.

Lajvanic, M. Constitutional Law and Constitutional Institutions (In Serb.) / Novi Sad, 2003.

Lukić, R. Introduction to Law (In Serb.) / Belgrade, 2004.

Marković, R. Constitutional law (In Serb.) / Belgrade, 2014.

Marković R. Ustav Republike Srbije od 2006-kritički pogled [Marković, R. Constitution of the Republic of Serbia since 2006: Critical view] (In Serb.); Belgrade University School of Law Publishing, 54 (2). 2006.

Pajvančić, M. Constitutional law (In Serb.) / Novi Sad, 2014.

Pajvančić, M. Law on Parliament (In Serb.) / Belgrade, 2008.

Pajvančić, M. Komentar Ustava Rebublike Srbije [Pajvančić, M. Commentary on the Constitution of the 
Republic of Serbia] (In Serb.) / KAS

Belgrade, 2009.

Pejić, I. Law on Parliament (In Serb.) /

Niš, 2011.

Petrov, V. Law on Parliament /

Belgrade, 2010.

Konstantin A. Polovchenko. (2019).

Normative Control of Law as the Basic

Power of Constitutional Court // Opción,

Año 35, Especial No.20 (2019). 12641276.

Konstantin A. Polovchenko (2019). Public prosecution service as an object of constitutional regulation // Revista Dilemas Contemporáneos: Educación, Política y Valores. Año: VI Número: Edición Especial Artículo no.:69 Período: Agosto, 2019

Konstantin A. Polovchenko Role of ombudsman in human rights protection in a contemporary state (2019). Role of ombudsman in human rights protection in a contemporary state // Opcion. Año 35, Especial No.19 (2019). 637-665.
Ponomareva, E.G. Dissertation on 'Formation of statehood in the postYugoslavian space: the internal and external factors' / Moscow, 2010.

Roskić, J. Constitution of the Republic of Serbia and Current Legal Practice / Belgrade, 2007.

\section{Simović, D. Racionalizovani}

parlamentarizam Ustava Srbij [Simović, D. Rationalized parliamentarianism of the 2006 Serbian Constitution] (In Serb.) / Belgrade Law Review: 14/2007

Stojanović, D. Legal status of the deputy (In Serb.) / Niš, 1999.

Stojanović, D. Constitutional law (In Serb.) / Niš, 2019.

Stojanović, D. Constitutional law (In Serb.) / Niš, 2014.

Stojanović, D. 'Basic characteristics and contents of Serbian constitution'. Facta Universitatis Nis. 2007.

Vasić, R., Jovanović, M., Dajović, G. Introduction to Law (In Serb.) / 
Periódico do Núcleo de Estudos e Pesquisas sobre Gênero e Direito

Centro de Ciências Jurídicas - Universidade Federal da Paraíba V. 9 - $\mathrm{N}^{\circ} 02$ - Ano 2020

ISSN | 2179-7137 | http://periodicos.ufpb.br/ojs2/index.php/ged/index

University of Belgrade Law Faculty

publishers, 2015 